\title{
BRITISH WARTIME CONTROL OF PRICES
}

\author{
James S. EARLBY* AND WiLLIAM S. B. LACY†
}

Price control has been an.integral part of Britain's war economy since hostilities began. The major objectives of the program have been several: the maintenance of morale; the preclusion of wartime economic disorganization; the minimization of post-war economic maladjustments; economy in government expenditure; and the prevention of unjust enrichment or impoverishment of different classes of the community. ${ }^{1}$ There have been two broad approaches to the problem: first, the prevention, so far as possible, of any rise in the general British price level; second, the control of specific prices in order, among other things, to prevent "profiteering." Broadly speaking, British authorities have permitted price advances based upon rising import costs or upon "justified" increases in domestic costs. Other price increases have been considered evidence of "profiteering," regarded as "inflationary," and have been combatted by the legislative and administrative regulation outlined below. The British have also attempted to curb the upward pressure upon costs and prices at the source by discouraging (but not prohibiting) the rise of wages, by very heavy taxation, and by an intense drive for saving.

Fiscal policy, propaganda, subsidy, legislation and administrative regulation have all been used as weapons in British price control efforts. It seems appropriate, however, to omit the first two from this discussion, since they raise questions somewhat outside the immediate subject of this symposium. The importance of fiscal policy to price control in Great Britain is indeed sufficient to justify extensive treatment, but

- A.B., 1932, Antioch College; M.A., 1934, Ph.D., 1939, University of Wisconsin. Associate Professor of Economics, University of Wisconsin. Senior Economist, Office of Price Administration and Civilian Supply, 1940-4x. Author: The British Cheap Money Program, r932-37.

+ B.A., 1932, University of Colorado. Chief of Foreign Information Unit, Office of Price Administration. Economist, Agricultural Adjustment Administration, 1934-36, National Resources Committec, I937, Federal Home Loan Bank Board, 1938; Financial Economist, Securities and Exchange Commission, 1938-40.

1 The official policy, with respect to price stabilization, has perhaps been best stated in the "White Paper" on the subject, Command 6294, issued July, I94I, as follows: "The beginning of the 'vicious spiral' of inflation is found in increased prices; these force a demand for increased wages which is generally followed by a further increase in prices and so on, indefinitely. It has always been found impossible to check inflation when it has gone beyond a certain stage. Consequently it is of the first importance to check: it at the beginning.

"By creating insecurity" and confusion it would impede our productive effort, give great opportunities to the profiteer and impose hardship on those who were not lucky enough to secure a share in the gencral advance of money incomes. People in receipt of old-age pensions, insurance benefits, or small fixed incomes would be able to buy less of the necessaries of life. At the same time the money costs of running the war would rise and the Goverament, unable to raise new tares sufficiently quickly, would bare to issue fresb money, which would further inflame the disease." 
such is impossible within the limited space available. Since, moreover, there are many price control agencies operating in the British war economy, it is necessary to confine attention mainly to those of major importance. Finally, detailed description of the techniques of regulation is deliberately sacrificed to permit delineation of the basic economic problems of price regulation which British experience has revealed as inevitable in the prosecution of total warfare, and to describe the manner in which legislative and administrative powers and techniques have been adjusted to cope with them. This type of analysis can best serve the main purpose of studying foreign experience: to make sure that our own authorities are possessed of power to take those steps necessitated by the economic problems of modern total warfare.

\section{Legislative Authorization and Administrattve Organization}

Price control in Great Britain has been administered by several agencies, of which three, the Ministry of Supply, the Ministry of Food, and the Board of Trade are the most important. The Ministry of Supply determines the price of industrial raw materials, whether destined for war or for civilian fabrication. The Ministry of Food administers the price of foodstuffs including animal feeds. The Board of Trade controls, pursuant to the Prices of Goods Act of November $16,1939,{ }^{2}$ and the Goods and Services (Price Control) Act of July 26, I94I, ${ }^{3}$ the prices of consumer goods other than foodstuffs, as well as prices charged by certain service industries.

The Ministries of War Transport (ocean and inland transport, and electricity rates), Petroleum, Health (rentals) and Mines (fuel) administer price control of those commodities and services for which each is responsible. The Treasury correlates the price control activities of all the Ministries identified above and is responsible for uniformity in price policy.

\section{The Ministry of Supply}

\section{A. Legislative Authority}

The Ministry of Supply was created pursuant to the Ministry of Supply Act of July 13, 1939. This Act, together with the Emergency Powers (Defense) Act I939 and, most importantly, Regulation $55^{4}$ issued pursuant thereto, empowers the Minister of Supply as a "competent authority" under the Act:

(r) To set maximum prices or specific prices.

(2) To prohibit or limit acquisition, disposition, production, use or delivery of a controlled commodity, by general or special direction or by licensing.

(3) To requisition supplies.

(4) To purchase, or contract to purchase, including the power to establish itself as sole purchaser.

(5) To sell commodities or contract for their fabrication.

(6) To examine documents and require returns.

(7) To license imports or exports (with the Board of Trade).

(8) To alter tariffs (with the Board of Trade).

\footnotetext{
23-4 GEO. VI, C. II8.

34-5 GEO. VI, c. 3I.

¿S. R. \& O., r939, No. 927 .
} 
(9) To levy charges (with the Treasury).

(Io) To establish and disperse pooling funds.

(II) To pay subsidies.

As the above powers indicate, the Ministry of Supply was created to perform broader functions than the administration of prices. The powers enumerated above, however, have been of the greatest importance in the administration of prices, by indirect as well as by direct control, as will be shown below.

\section{B. Administrative Structure}

The Ministry of Supply undertakes to perform the dual function of assembling supplies of industrial raw materials for both military and civilian use, and of directing those supplies destined for military use through the industrial system. Accordingly the Ministry is divided into two major departments designed to perform those functions: the Raw Materials Department and the group of Directors General described below. Responsible to a Secretary to the Minister is the Raw Materials Department, which is divided into sections, each of which is concerned with one or more raw materials. ${ }^{5}$ Responsible to another Secretary to the Minister are five Directors General, each in charge of the production of a finished military good. ${ }^{0}$ Other Secretaries of the Minister preside over certain service departments, ${ }^{7}$ whose functions are to provide necessary information or technical advice to the entire Ministry.

The ultimate authoritative group in the Ministry is the Supply Council, which is composed of the Minister of Supply as chairman, the Secretary in charge of the Raw Materials Section, the Directors General of Munitions Production, Explosives, Tanks and Transports, Ordnance Factories, Finance, and five industrialists and financiers who voluntarily offer part-time assistance and advice.

For each commodity controlled by the Ministry's Raw Material Department, ${ }^{8}$ which is directly concerned with the problem of price control, there is an industrial "control" organization, responsible to and deriving all powers from the Minister. The "Control Boards" are composed of representatives of the industry chosen by the Minister and serving usually as temporary civil servants, sometimes without remuneration. The "Controller" and his assistants have often been drawn from that industry which they presently control as public officials, and in many cases are officials of trade associations. Each Control implements those decisions of the Supply Council, which relate to the commodities for which it is responsible. Since policies made by the Supply Council are generally of a broad character, the activities of the Control in many cases determine the nature of government administration of the industry.

\footnotetext{
- The latest available information designates these sections as follows: Iron and Steel, Ferro-alloys, Abrasives, Refractories, Non-ferrous Metals, Chemicals, Sulphuric Acid, Fertilizers, Mercury, Molasses, Alcohol, Pigments, Timber, Cotton, Rubber, Mica, Building Materials, Wool, Leather, Paper, Flax, Hemp, Jute, Silk, Rayon, and Miscellaneous.

- Equipment and Stores, Tanks and Transport, Explosives and Chemical Supplies, Munitions, Ordnance.

Typical designations as follows: Finance, Military Advisor, Public Relations, Establishments, Scientific Research.

${ }^{8}$ See note 5, supra.
} 
The price of each commodity is determined by the Ministry's Raw Material Department after suitable consultation with the Finance Department, industrial advisory committees, and the Treasury. The Control itself undertakes the enforcement of the price levels set by the Ministry. The principles of price determination will be discussed in a subsequent section.

\section{The Ministry of Food}

\section{A. Legislative Authority}

The Ministry of Food was created by Order in Council September 6, 1939, issued pursuant to the Ministers of the Crown (Emergency Appointments) Act of $1939 .^{\circ}$ The Ministry of Food took over, upon its creation, the Food (Defense Plans) Department which had been organized in the Board of Trade December, 1936, to anticipate the problems of wartime food administration.

As a "competent authority," the Minister of Food was empowered by Regulation 55 to execute the same powers granted to the Minister of Supply. These powers include the authority to regulate or prohibit the production, treatment, keeping, storage, movement, transport, distribution, disposal, acquisition, use or consumption of foods and animal feed. The Ministry has power to demand complete access to the books, records, and the premises of any company; it may purchase abroad, process foodstuffs itself, and fix prices and margins at any stage of production and distribution. To implement the above powers, the Ministry of Food is authorized to grant or refuse licenses.

\section{B. Administrative Structure}

The principal responsibilities of the Ministry of Food are to insure an adequate and reliable supply of essential foodstuffs and to distribute them on an equitable basis at as reasonable prices as possible. The Ministry of Food is divided into three principal divisions, each responsible (directly or through his secretariat) to the Minister. The Supply Division, presided over by the Minister's Commercial Secretary, operates the Commodity Controls, each one of which administers one or more classes of goods or services over which the Ministry has jurisdiction. ${ }^{10}$ Each Control is responsible to a Principal Assistant Secretary, a senior civil servant, who, while directly responsible to the Minister's Commercial Secretary has, in fact, direct access to the Minister. The Ministry of Food's Controls are staffed with Civil Servants or persons drawn from the trades but in the actual employ of the Ministry. Each Control has many functions, officially described as follows:11 "The Staff of the Supply Division may be concerned with the actual purchase and sale of the commodities (in cases where the Ministry itself does the trading), with negotiating with the

\footnotetext{
S. R. \& O., 1939, No. III9.

${ }^{10}$ A Control exists for each of the following commodities: Animal Feedstuffs, Bacon and Hams, Canned Fish, Canned Fruits and Vegetables, Cereals, Cocoa, Condensed Milk, Dried Fruits, Imported Eggs, Meat and Livestock, Oils and Fats, Potatoes, Sugar, Tea, Imported Fresh Fruit and Vegetables, Cold Storage, Freights, Transport.

${ }^{11}$ Select Comattiee on National Expenditure, Fourth Report (May 7, r940), p. 28.
} 
trading interests concerned in the manufacture, processing and wholesale or retail distribution of all controlled commodities, with fixing the margins to be allowed to the trading interests for performing the functions just mentioned and with retail selling prices of the final production."

The Division of Emergency Feeding, Rationing, and Divisional Food Offices is administered by a Deputy Secretary responsible to the Minister's Permanent Secretary. This Division licenses and supervises wholesale and retail traders, administers the Regional Food Offices, operates rationing schemes, and is responsible for all enforcement. The divisional Food Offices are in close administrative relations with the commodity controls described above.

The Planning Division, administered by a Deputy Secretary responsible to the Minister's Permanent Secretary, is responsible for the following assignments: The correlation of economic policy (including price policy), the planning of imports (including the implementation of the Lease-Lend Program), supervision of the Ministry's foreign relations, the correlation of domestic production plans, and the Ministry's relations with all other government departments.

Besides the three divisions identified above, there are in the Ministry four "Service Divisions": the Legal Division, the Finance Division, the Public Relations Division, and the Costings (Margins) Division. The nature of the work of each is indicated by their designations. Each collaborates with the others, providing their specialized knowledge to the prosecution of the vast work of the Ministry.

Of great importance in the actual day-to-day operation of the Ministry are the Standing Committees, usually appointed ad hoc to deal with a particular problem. Such committees are composed as follows: The Chairman, a Commercial Secretary; the members, those Principal Assistant Secretaries, in charge of the commodity controls, concerned; a representative of the Freight Division; a representative of the "service" division especially concerned, e.g., legal, costings, rationing or planning. The activities of one of these committees, the Standing Committee on Margins, will be discussed below. The Committees have no executive powers and serve principally as instruments for threshing out difficult problems; they dissolve on the completion of their particular task.

Administrative machinery, by means of which food prices are fixed, consists of the following: The Commodity Control supplies its recommendation as to price fixing, made in the light of its intimate knowledge of the trade, to the Interdepartmental Committee on Food Prices. This latter body makes final recommendations which are implemented by the Control and enforced by the Regional Food Offices. Members of the Interdepartmental Committee on Food Prices represent the Ministry of Food, the Treasury, the Ministry of Agriculture, the Scottish Department of Agriculture, the Ministry of Agriculture of Northern Ireland, the Ministry of Labour, the Ministry of Health, the Prime Minister's department and economic Secretariat of the Cabinet Offices. Attached to the Food Price Committee and comprising essentially the same membership is a sub-Committee called the "Agricultural Prices 
Committee," which makes recommendations as to the prices to be paid to producers. The three Agricultural Departments mentioned above have representatives upon this Committee but not upon the Food Price Committee.

Board of Trade

\section{A. Legislative Authority}

This article is concerned, of course, with only those activities of the Board of Trade which contribute to price administration. The Board of Trade participates in price control in the following ways:

(I) As the agency charged with the administration of the Prices of Goods Act and its supplement, the Goods and Services (Price Control) Act, the purpose of both of which is to control the prices of non-food consumers' goods and certain services.

(2) As the agency charged with the regulation of civilian industry, by means of its licensing power, the Limitations of Supplies Orders, and the recent plan for the concentration of civilian industry.

(3) As the Ministry primarily responsible for import-export policy.

The Prices of Goods Act of 1939 provides for the regulation of prices in two ways: ( $I$ ) in accordance with the statutory requirement (Section $I$ ) that a price-regulated good shall not be sold above a price equal to a "basic price" (normally that of August 2I, I939) plus a "permitted increase," described below; (2) by the administrative determination of a specific "permitted price" for price-regulated goods of any description (Section 5). Immediately a good is declared a "price-regulated good" by the Board of Trade, it becomes subject to regulation under the first method described above; this regulation may be superseded, at the discretion of the Board, by the second method. The first method is called the "permitted increase" method, the second the "permitted price" method, of price control.

To overcome inadequacies of the Prices of Goods Act which are described below, the Goods and Services (Price Control) Act was passed, July 26, I941. This act conferred upon the Board of Trade the following powers:

(r) To fix, for manufacturers, wholesalers, and retailers, either maximum prices or maximum percentage margins of profit.

(2) To fix maximum prices charged for services which directly affect consumer goods prices, such as shoe repairing, furniture storage, cleaning and pressing, etc.

(3) To minimize the activities of unnecessary middlemen.

(4) To establish an official price control organization in the field through the appointment of an adequate inspectorate.

\section{B. Administrative Structure}

The administrative organization in the Board of Trade for the execution of the Prices of Goods Act and the Goods and Services (Price Control) Act is very simple. Upon the passage of the Prices of Goods Act, the Board of Trade selected a Central Price Regulation Committee responsible directly to the President of the Board to act as the administrative and policy-making head of its price regulative organization. 
This Committee is responsible for the fixing of "permitted prices," "basic prices," and "permitted increases." It determines the scope of regulation and the character of prosecution. The Board constitutes "ultimate authority" and may overrule the Committee.

The Committee is composed of technical experts and representatives of the interests affected by the Act. The original committee was composed as follows: an eminent barrister for chairman; for members, the director of a large department store, an economist, an accountant, a trade union leader, a trade association director, a member of the London County Council, a cooperative leader, and a warehouseman.

A local Price Regulation Committee has been organized in each of the 17 "Wartime Regions" of Britain, each composed of representatives of the interests affected by the Act. These Committees execute the policies made by the Central Committee, hear complaints, initiate investigations and make appropriate representations to the Central Committee.

The above organization, augmented by an inspectorate charged with local enforcement, also administers the new Goods and Services (Price Control) Act.

\section{Price Poutcres}

\section{A. Price Control by the Control of Profit}

One of the major aims of the British price control program has been the restriction of profits to a "reasonable" level. Price determination by the Ministries of Supply, Food, Shipping, and Transport has been based upon the maintenance of profits at "normal" levels, although, as will be shown below, regulation is extended well beyond this limited objective. Prices of industrial raw materials have been fixed by the Ministry of Supply at levels calculated to be reasonably remunerative to domestic and overseas producers. Initial prices were commonly set very near those prevailing in the immediate pre-war period and were subsequently revised from time to time (usually upward) on the basis of increases in import or domestic costs. The Ministry of Food has professedly followed a similar policy, and in fixing margins for storage, transport and wholesale and retail distribution, its declared policy has been to preserve their pre-war levels, with adjustment for wartime changes, so as to yield "fair remuneration" to the trades concerned. ${ }^{12}$ The only effort to control prices by administrative fiat on the "reasonable profit" principle, without the aid of regulation of supply, demand or distribution, has, however, been by the Prices of Goods Act summarized above.

The objective of this Act was to "freeze" sellers' pre-war net income, although this principle was not expressly stated. Whether a price-regulated good is subject to the statutory requirement of sale at not more than the "basic price" plus the "permitted increase" or to an administrative regulation setting the (maximum) permitted price, ${ }^{13}$ in either case, the seller's pre-war net income is to be retained under regulation. The

\footnotetext{
12 See Select Conmittee on National Expenditure, Fourth Report, May 7, 1940, p. 32, and Eleventh Report, Aug. 8, 1940, p. I2. See also p. I68, infra.

${ }^{18}$ These alternatives are described on p. 165 , supra.
} 
Act specifies that the price of any price-regulated good shall not exceed that charged by the same seller on August 2I, I939 by more than an amount (the "permitted increase") equal to the increased cost of selling that article above the level of cost on the base date (Section 4). The factors to be considered in determining this permitted increase, as well as an administratively determined permitted price, are set forth in a schedule to the Act; the Board of Trade may add others by order. The schedule is comprehensive, including: the cost of goods to the seller; manufacturing; processing and operating expenses of all kinds; selling costs; and "the total volume of the business over which the overhead expenses thereof fall to be spread."14

The seller can therefore add all increased direct costs, and if he experiences decreased volume he can legally charge prices sufficiently high to compensate for increased overhead costs per unit. Although the recent Goods and Services (Price Control) Act extends the scope of control of prices of non-food consumer goods, adds control of the prices charged by certain service industries, and provides for more adequate enforcement, the principle of regulation remains the same.

Although the Prices of Goods Act has unquestionably helped prevent profiteering, experience has amply demonstrated that in conditions approaching total war this type of price regulation is inadequate. Throughout its life, there have been persistent complaints of non-enforcement of the Act. Up to the end of August I940 prosecution had been recommended in only 37 cases, and total fines imposed, including costs, totalled only $f_{189} .^{15}$ Even where prices have been held to the level permissible under the Act, it has become clear that they have risen further and more rapidly than official policy could countenance, and that control over supply, demand and distribution is essential. British experience demonstrates admirably what would be expected a priori under such circumstances. Even if, by virtue of patriotism or rigid enforcement, prices are kept within limits of "reasonable profitability," actual rises in prices are likely to be great, and the creation of other problems fully as serious as rising prices is inevitable.

In wartime, increased costs are certain to result from several factors: increased import costs (particularly important, of course, in Britain); higher costs of obtaining additional increments of domestic production; decreased efficiency caused by diversion of facilities from customary to wartime activities and attempts to operate industrial units at high levels of intensity; rising wage rates. In addition, many plants in civilian industry will have to work at far below optimum levels of output, so that if price regulation is aimed, as has been the Prices of Goods Act, at preserving the level of profits, prices will have to be raised sharply to permit the covering of overhead on the smaller volume.

As a result of these factors, most of which have operated with especial force in Great Britain, the British have found that prices justified on the profit criterion are in many cases higher than equity, the maintenance of national morale, or the restrain-

\footnotetext{
2s See Prices of Goods Act, First Schedule.

${ }^{15}$ Central Price Regulation Committee, Statement to the Press, Sept. 5, 1940, p. x.
} 
ing of wage advances would dictate. Subsidies at the rate of about $\$ 400$ million per year have been paid to keep down the price of certain essential foodstuffs; in introducing the Budget for $194 \mathrm{I}-42$, the Chancellor of the Exchequer announced the Government's intention of extending subsidy in the current fiscal year to railway fares, fuel prices, utility charges and the prices of "other articles in common use," in order to keep the cost of living at about its current level (roughly $28 \%$ above prewar).$^{10}$ If this program is carried through, it. will represent the abandonment of the effort to control prices in accordance with the "fair profit" formula, even though the prices paid to suppliers may continue to be fixed by that criterion.

In any case, the fixing of prices with reference to costs and profits, even if it succeeds, will not solve the problems which a price regulation authority faces in modern war. Those who fix prices have the task of providing for the supplies and regulating the consumption of the goods controlled, unless they are willing to set them at the level which the market would in any case hit upon. The price which is "reasonable" in that it gives to industry approximately the necessary, or "pre-emergency normal," profit may be insufficient to insure adequate supply; it is almost certain to be insufficiently high to restrain consumption within the limits of available supply.

As indicated below, the Ministries of Supply and Food have been able to cope with these problems by regulation of supply, distribution and demand through their powers under the emergency legislation described above. Only the Prices of Goods Act administrators, who have possessed no such power, have had to content themselves simply with fixing prices on the "fair profit" basis and permitting either evasion or disequilibria between demand and supply.

\section{B. Price Control Through Supply Controls}

To maximize available supply, the Ministries of Food and Supply (in collaboration with the Import-Export Departments of the Board of Trade), have, pursuant to their above-described powers, purchased abroad large supplies of commodities required for the maintenance of a war economy. Large stocks of rubber, wool and cotton have been obtained at favorable prices through trade agreements with the countries of origin, some of these agreements providing for payment through barter, some for payment in cash, and still others through the extension of credit. In respect to other commodities, such as iron and steel, the available supplies were increased not only by maximizing imports but by increasing domestic production. These practices not only gave the Ministries control over possible short-term market behavior, but have also protected the British economy against longer-term price increases accompanying the probable development of world-wide shortages.

In addition to the above means of forestalling price increases, various financial devices have been employed to prevent prices from reflecting fully the influence of the high-cost producers. For example, the iron and steel industry has found it necessary to use larger proportions of high-cost imported materials during the war than

\footnotetext{
${ }^{10}$ See p. 171, infra.
} 
in peacetime. In order that domestic prices of steel should not be unduly influenced by these import costs, a levy has been imposed on the domestic production of steel and the resulting fund has been used to meet losses incurred on the sale of imported steel by the Control. Similar "cost-equalization" schemes have been used in the control of prices for timber and certain foodstuffs.

Outright Treasury subsidy has also been employed to restrain the prices of certain foodstuffs from rising by the full amount of increased import costs. Customs duties have been remitted, food processors have been supplied with raw materials at prices below actual costs to the Government, meats and milk have been sold to retail distributors at prices below those paid their producers by the Government, and in other cases the Ministry of Food sold portions of its stocks in the open markets at less than cost price in order to prevent prices from rising.

In summary, the Ministry of Food is the sole procurer of most of the essential foodstuffs for human and animal consumption, and the Ministry of Supply is in the same position in respect to most of the important industrial raw materials for which it is responsible. By virtue of their control of supply, the Ministries of Food and Supply have been able to exert a degree of control over the British price structure that would otherwise have been impossible.

\section{Price Control through Control of Distribution}

British experience has proven conclusively that successful control of prices requires regulation of large sections of the processes of distribution. The relative success of the Ministries of Supply and Food may be accredited in large part to the extension of their control of commodities through several stages of distribution, licensing of dealers and specific transactions, and the supervision of distribution by means of priority and rationing.

The importance of such control can perhaps best be illustrated by the difficulties encountered by the Board of Trade in administering the Prices of Goods Act, which provided no control over distributive processes. As a result, there were not only frequent straight violations of the Act, but legal schemes of evasion flourished. "Irregular" middlemen appeared, who purchased goods from wholesalers and even retailers, for the purpose of selling either illegally or at an advanced price based on the "cost" which they had incurred. Goods often passed through a number of these intermediaries, each of whom raised their price. (This practice was encouraged by the limitation of most regulations under the Act to retail prices.) A more "respectable" practice was to hoard supplies of price-controlled goods until their price had perforce to be raised to bring them on the market. ${ }^{17}$

The Goods and Services Act was designed in large part to fill such gaps in the price control structure. In addition to extending the scope of regulation to secondhand goods and certain service industries, and providing for an inspectorate for enforcement, the Board of Trade was empowered by the new Act "to check all

${ }^{17}$ See 141 Ecovomist, March 15, x941, p. 335. 
profiteers, commission agents, middlemen and speculators alike, as well as to make official control of margins, wholesale, retail and manufacturers', comprehensive enough to be effective." In consonance with these powers the Board was also given the power to fix either maximum prices or maximum percentage margins of profit for all manufacturers, wholesalers and retailers. In this way price control of non-food consumer goods was placed more on a par with the more successful control of foods and industrial materials.

Certain activities of the Ministry of Food also illustrate the baneful results of applying maximum prices to goods over the distribution of which no regulation is exercised. In the case of essential foods, price-fixing was reinforced either by purchase and distribution by the Ministry itself or, at the least, by licensing of importers and retailers. But in the case of other foods, the control of which was initially considered of little importance, maximum prices were imposed only when prices began to get out of control, distribution was left in the hands of unlicensed private wholesalers. As a consequence, the supplies were bought up by speculators and, disappearing from sale at licensed retail shops, were distributed at illegal prices through "black markets."18

\section{Price Control through Priority, Allocation and Rationing}

Experience of all countries indicates that in total war the supplies of goods can never be made sufficient to meet aggregate demands at stable prices. The arms sector of the economy inevitably requires resources which can be released from civilian employment only by sharply rising prices or administrative throttling of expenditure by civilian users.

Through the use of priorities, allocation, and rationing the British authorities, in addition to conserving scarce goods and services for the war effort, have significantly contributed to the stabilization of the price structure. These demand-controlling measures have been employed in connection with three major price control efforts: industrial raw materials, essential foods and feeds, and clothing. ${ }^{10}$ 'The only major price control program which has not been aided by such means has been that for non-food consumer goods. That effective means to restrain civilian demand are essential to successful price stabilization is illustrated by British experience in these fields.

The Ministry of Supply in its control of raw material prices has been able, as a result of its comprehensive powers, virtually to exclude the demands of "non-essential" industrial consumers by establishing priority for defense needs and essential civilian services. Later in the war the priority technique was supplanted in some cases by more elaborate schemes of allocation and licensing, by which total available supplies of raw materials have been allotted for definite periods to preferred indus-

\footnotetext{
${ }^{18}$ The situation became a public scandal. See I4I Economist, May 3, 1941, p. 584; id. May 10, 1941, p. 6 i8.

${ }^{20}$ Similar controls have been exercised in the case of labor, transport, foreign exchange, etc.
} 
trial users. For example, from April r940 on, only those uses of steel sanctioned by the official allocation schedules have been permitted, and competitive demand for iron and steel thus practically eliminated.

The Ministry of Food has possessed unlimited power to use what is essentially the same technique-consumer rationing-in its control of food prices. It has exercised this power through the rationing of "essential" foods (meats, butter, margarine, other fats, sugar, tea, milk, eggs, cheese, and marmalades). Since demand could be controlled by the use of such techniques, prices could be fixed and maintained without setting up pressure from unsatisfied buyers.

The inability or failure of certain British price authorities to exercise this control of demand has proven the great importance of such control to successful price stabilization. For example, the Ministry of Food has left unrationed all those foods which were not considered "essential" or the supplies of which were not considered vulnerable. The increased scarcity of some of these, together with the rise of wartime money income and the natural tendency to substitute unrationed foods for those which could be purchased in only very limited quantities, exerted strong upward pressure upon their prices. As a result the uncontrolled demand has led to queues, evasion of price orders, and, in many cases, the disappearance of price-fixed but unrationed foods from the regular markets.

Another example of attempting to control prices without curbing demand is the case of non-food consumer goods under the Prices of Goods Act and the Goods and Services (Price Controls) Act. These acts carry no power to control consumption. The omission was the more serious because the supply of many non-food consumer goods was severely restricted as the progress of the war necessitated giving such products low priority ratings, the conversion of civilian plant and labor to more essential production, and the direct limitation of supply by the Limitations of Supplies Orders. ${ }^{20}$

Consequently the control of non-food consumer goods prices was, by the spring of I94I, an admitted failure. This failure was reflected most clearly by the behavior of clothing prices. By May I94I the price of clothing in the Ministry of Labour's Cost of Living Index (the only category under the jurisdiction of the Act for which a reliable index number is available) had risen about $75 \%$ above its pre-war level, while the total Cost of Living Index had risen by only about $29 \%$, retail food by only $25 \%$, rent by only $\mathrm{r} \%$, and fuel and light by only $25 \%{ }^{21}$

Two remedial measures have recently been imposed. The first is the Goods and Services Act, which improved enforcement and extended control over distribution. The other, which attacks the source of much of the difficulty existing in this phase of

\footnotetext{
${ }^{20}$ The Limitations of Supplies Orders issued by the Board of Trade began to appear in the late spring of 1940 . From June $I$, 1940, they cut the supplies of a large number of consumers' goods to $662 / 3 \%$ of the base period June I to November 30, 1939. They have been extended in scope and severity since that time. Typical quotas are now $25 \%-33 \mathrm{x} / 3 \%$ of December $\mathrm{x}$, 1939-May 30, 1940 levels.

${ }_{21}^{21}$ Typical wholesale price increases include: Coal $33 \%$, Food $60 \%$. The wholesale price index rose $54 \%$ from August 1939 to March I94I.
} 
price control, was the institution of consumer rationing of clothing, boots and shoes, cloth and knitting wool on June I, I94I. Now that the effective demand for clothing has, presumably, been adjusted to available supplies, the problem of controlling clothing prices should be less difficult. Other non-food consumer goods are, however, still subject only to the control of prices and distribution under the Prices of Goods Act and the Goods and Services Act.

British experience indicates unmistakably that the control of raw materials and food prices alone is insufficient for effective stabilization of the price structure. The problem of controlling prices of non-food consumers' goods cannot be avoided, nor handled lightly, in any "full war effort" in which price stabilization is an objective. The control of prices of essential raw materials may perhaps be relied upon to keep this sector of the price structure stable so long as resources for consumers' goods production are plentiful; but once large segments of resources must be diverted from consumption goods production, as is inevitable in total warfare, no such simple approach to price stabilization will suffice. Under these conditions effective control of the prices of non-food items in the cost of living requires very strong legislation, vigorous enforcement, and-quite probably-the aid of consumer rationing. 